\title{
PENGARUH BUDAYA ORGANISASI TERHADAP KINERJA PEGAWAI PADA KANTOR KEMENTERIAN AGAMA (KEMENAG) KABUPATEN BIMA
}

\author{
Nuranisyah $^{1}$, Firmansyah Kusumayadi ${ }^{2}$ \\ ${ }^{1,2}$ Program Studi Manajemen,Sekolah Tinggi Ilmu Ekonomi Bima \\ Jln. Wolter Monginsidi Komplek Tolobali, Kota Bima \\ Email: firmansyah90.stiebima@gmail.com
}

\begin{abstract}
Abstrak
Penelitian ini bertujuan untuk mengetahui pengaruh budaya organisasi terhadap kinerja pegawai pada Kantor Kementerian Agama Kab. Bima. Instrumen penelitian kuesioner. Teknik skor yang digunakan dalam kuesioner penelitian ini adalah skala Likert. Populasi penelitian seluruh pegawai Kementerian Agama (KEMENAG) Kabupaten Bima. Selanjutnya untuk menentukan ukuran sampel menggunakan teknik pengambilan sampel puposive sampling dimana populasi dijadikan sampel berdasarkan kriteria dengan jumlah sampel sebanyak 34 PNS. Hasil penelitian menunjukkan bahwa budaya Organisasi berpengaruh positif terhadap kinerja pegawai.
\end{abstract}

Katakunci: Budaya organisasi; Kinerja pegawai; Kemenag

\begin{abstract}
Abstrack
This study aims to determine the influence of organizational culture on employee performance at the Office of the Ministry of Religion Kab. Bima. Questionnaire research instrument. The scoring technique used in this research questionnaire is a Likert scale. The research population was all employees of the Ministry of Religion (KEMENAG) Bima Regency. Furthermore, to determine the sample size using a purposive sampling technique where the population is sampled based on criteria with a sample of 34 civil servants. The results showed that organizational culture had a positive effect on employee performance.
\end{abstract}

keyword : Organizational culture; Employee Performance; Ministry of Religion.

\section{PENDAHULUAN}

Era globalisasi menjadikan pegawai sebagai salah satu aset yang sangat penting bagi suatu organisasi dalam menghasilkan kinerja yang efektif dan efisien. Fungsi sumber daya manusia dalam suatu organisasi merupakan salah satu fungsi pendukung yang berperan sangat penting dalam kelancaran proses pengelolaan organisasi secara utuh. Secara keseluruhan tujuan organisasi ditentukan oleh kinerja pegawainya. Disamping itu, dalam sebuah organisasi terdapat nilai-nilai dan kepercayaan yang dianut oleh sebuah organisasi dalam praktek kesehariannya yang dinamakan sebagai budaya organisasi. Bagaimana pegawai bersikap dan berperilaku serta apa yang seharusnya mereka lakukan banyak dipengaruhi oleh budaya organisasi tersebut. Sikap yang dibentuk antara lain oleh budaya organisasi erat dengan kinerja pegawai. Sedangkan tujuan organisasi secara keseluruhan ditentukan oleh kinerja pegawai. Kesuksesan sebuah organisasi tidak hanya didukung oleh budaya organisasi tetapi juga bagaimana organisasi tersebut menumbuhkan komitmen organisasi yang dipahami sebagai ikatan kejiwaan individu terhadap organisasi.

Organisasi harus benar-benar memperhatikan kebutuhan para pegawainya agar kinerja pegawai tetap maksimal dan tujuan organisasi bisa tercapai. Banyak cara yang bisa ditempuh oleh organisasi untuk meningkatkan kinerja pegawai. Misalnya berupaya untuk membuat pegawai merasa nyaman dalam suasanan kerjanya agar bisa mempertahankan produktivitasnya dan menghasilkan kinerja 
positif sehingga tujuan-tujuan organisasi dapat dicapai. Robbins (2012) mengatakan semua organisasi memiliki budaya, namun tidak semua budaya organisasi sama kuatnya dalam mempengaruhi perilaku dan tindakan para pegawai. Budaya yang kuat yaitu budaya yang menanamkan nilai-nilai utama secara kokoh dan diterima secara luas dikalangan para pegawai dan memiliki pengaruh yang lebih besar terhadap perilaku para pegawai dibandingkan dengan budaya yang lemah.

Budaya organisasi terdiri atas unsur nilai-nilai dasar yaitu integritas (keselarasan antara hati, pikiran, perkataan dan perbuatan yang baik dan benar), profesionalitas (bekerja secara disiplin, kompeten dan tepat waktu dengan hasil terbaik), inovasi (menyempurnakan yang sudah ada dan mengkreasi hal baru yang lebih baik), tanggung jawab (bekerja secara tuntas dan konsekuen), dan keteladanan (menjadi contoh yang baik bagi orang lain). Untuk menerapkan suatu budaya organisasi bukanlah suatu pekerjaan yang mudah karena pada dasarnya pegawai mempunyai karakteristik tingkah laku yang berbeda sesuai dengan tingkat kebutuhannya. Budaya organisasi seharusnya mengacu kepada tatanan aturan yang berlaku di organisasi, demi terciptanya keharmonisan perilaku pegawai dalam bekerja terhadap tujuan yang hendak dicapai perusahaan. Budaya organisasi menjadi pegangan/pondasi dasar bagi pegawai dalam mengikuti aturan yang berlaku, sehingga norma-norma yang berlaku tersebut menjadi sumber pengarahan pegawai untuk mencapai kinerja yang optimal. Salah satu upaya organisasi dalam membuat nyaman para pegawai dengan menciptakan budaya organisasi yang kuat dan selalu memotivasi pegawai. Budaya organisasi tercipta dari pemimpin menginginkan agar pegawai selalu memiliki kinerja optimal dan bekerja dengan nyaman.

Berdasarkan hasil observasi awal yang dilakukan oleh peneliti bahwa terkait dengan budaya organisasi yang masih dirasakan sepenuhnya lemah sehingga berdambak pada kinerja pegawai yang belum optimal pada Kantor Dinas Sosial Kota Bima. Lemahnya budaya organisasi yang dirasakan terjadi karena beberapa pegawai sering keluar masuk kantor tanpa kepentingan dan alasan yang jelas sehingga terlihat kurang disiplin, selalu menunda pekerjaan, dan sering menunggu perintah dalam melakukan pekerjaan sehingga kurang maksimal karena dilakukan secara tergesagesa. Disamping itu terkait masalah kinerja pegawai yang kurang optimal yaitu beberapa pegawai masih sering melakukan kesalahan dalam bekerja, dan tidak dapat menyelesaikan pekerjaan dengan tepat waktu karena jam kerja dihabiskan untuk bercerita dan menunda pekerjaan, serta menunggu perintah dari atasan tanpa inisiatif bekerja ditandai dengan banyaknya pekerjaan yang dikerjakan di akhir-akhir pelaporan sehingga banyak terjadi kesalahan dan terlambat mengumpulkan pelaporan sehingga menurunkan kinerja pegawai di kantor Kementerian Agama (KEMENAG) Kabupaten Bima.

Berdasarkan uraian latar belakang diatas,maka penulis tertarik mengambil

judul, "Pengaruh Budaya Organisasi Terhadap Kinerja Pegawai pada Kantor Kementerian Agama (Kemenag) Kabupaten Bima".

\section{KAJIAN PUSTAKA \\ Budaya Organisasi}

Budaya Organisasi Menurut Robbins (2007), budaya organisasi sebagai sebuah sistem makna bersama yang dianut oleh para anggota organisasi yang membedakan organisasi tersebut dengan organisasi lain. Menurut Sutrisno (2011), budaya organisasi merupakan suatu kegiatan sosial yang tidak tampak, yang dapat 
menggerakkan pegawai dalam suatu organisasi untuk melakukan aktifitas kerja. Sedangkan menurut Perucci (Tampuboleon, 2014:184), budaya adalah segala sesuatu yang dilakukan, dipikirkan dan diciptakan oleh manusia dalam masyarakat serta termasuk pengakumulasian sejarah dari objekobjek atau perbuatan yang dilakukan sepanjang masa.

Indikator budaya organisasi menurut Robbins (2007):

a. Inisiatif individual yaitu tingkat tanggung jawab, kebebasan atau independensi yang dipunyai setiap anggota organisasi dalam mengemukakan pendapat,

b. Pengarahan yaitu sejauhmana organisasi dapat menciptakan dengan jelas sasaran dan harapan yang diinginkan,

c. Integrasi yaitu sejauhmana suatu organisasi dapat mendorong unit-unit organisasi untuk bekerja dengan cara yang terkoordinasi,

d. Dukungan manajemen yaitu sejauhmana organisasi memberi dukungan dalam upaya pengembangan kemampuan para pegawai seperti mengadakan pelatihan,

e. Kontrol yaitu adanya pengawasan yang dilakukan dalam organisasi terhadap perilaku para pegawai dalam melaksanakan tugasnya dengan berpedoman peraturan yang telah ditetapkan,

f. Sistem imbalan yaitu sejauhmana alokasi imbalan seperti kenaikan gaji, promosi, dan sebagainya didasarkan atas prestasi kerja pegawai,

g. Pola komunikasi yaitu sejauhmana komunikasi dalam organisasi yang dibatasi oleh hierarki kewenangan yang formal dapat berjalan dengan baik.

\section{Kinerja Pegawai}

Menurut Sedarmayanti (2011), kinerja merupakan terjemahan dari performance yang berarti hasil kerja dari seorang pegawai, sebuah proses manajemen atau suatu organisasi secara keseluruhan, dimana hasil kerja tersebut harus dapat ditunjukkan buktinya secara konkrit dan dapat diukur. Menurut Wibowo (2010), Kinerja adalah tentang melakukan pekerjaan dan hasil yang dicapai dari pekerjaan tersebut. Sedangkan menurut Mangkunegara (2012), Kinerja pegawai (prestasi kerja) adalah hasil kerja secara kualitas dan kuantitas yang dicapai oleh seseorang pegawai dalam melaksanakan tugasnya sesuai dengan tanggung jawab yang diberikan kepadanya. Berdasarkan beberapa definisi di atas, disimpulkan bahwa kinerja adalah hasil kerja baik kualitas maupun kuantitas, yang dihasilkan oleh pegawai. Kinerja tinggi para pegawai akan membuat perusahaan lebih cepat dan mudah mencapai tujuannya.

Indikator Kinerja pegawai menurut Hasibuan (2012) menyatakan bahwa keberhasilan karir dipengaruhi oleh:
a. Kesetiaan
b. Prestasi Kerja
c. Kedisiplinan
d. Kerjasama
e. Kecakapan
f. Tanggung Jawab

\section{Pengaruh Pengembangan Karir terhadap Kepuasan Kerja}

Salah satu peranan penting nilai-nilai di dalam budaya organisasi terhadap kinerja pegawai adalah melalui peningkatan motivasi. Hubungan kinerja yang maksimal dengan budaya organisasi melalui motivasi tampak jelas dirasakan oleh 
perusahaan yang memiliki filosofi/esensi nilai-nilai yang kuat baik dari sisi lingkungan internal maupun terhadap lingkungan eksternal perusahaan. Tika (2016) menyatakan bahwa budaya organisasi membantu kinerja karena menciptakan suatu tingkat motivasi yang luar biasa bagi pegawai.

Menurut Gibson dalam Sutanto (2013), pegawai atau karyawan sebagai penggerak operasi organisasi, jika kinerja pegawai baik, maka kinerja organisasi juga akan meningkat. Banyak variabel yang mempengaruhi kinerja pegawai salah satunya budaya organisasi. Budaya organisasi sebagai persepsi umum yang dimiliki oleh seluruh anggota organisasi, sehingga setiap pegawai yang menjadi anggota organisasi akan mempunyai nilai, keyakinan dan perilaku sesuai dengan organisasi.

Budaya organisasi merupakan salah satu strategi untuk memotivasi bagi pegawai untuk mencapai kinerja yang maksimal, karena budaya organisasi yang baik dengan sendirinya akan memberikan suatu kondisi yang sesuai dengan perilaku pegawai dalam bekerja apabila budaya tersebut sangat cocok dan mendukung pegawai dalam mengembangkan kemampuan dan menopang kesejahteraannya dengan kata lain, budaya organisasi menjadi faktor penting untuk meningkatkan kinerja pegawai (Wirawan, 2007).

\section{Pengembangan Hipotesis}

\section{H1 : Hubungan Parsial antara Budaya Organisasi dan Kinerja Pegawai}

Ho $; \beta=0$, Tidak terdapat pengaruh Budaya Organisasi secara signifikan terhadap Kinerja Pegawai pegawai pada Kementerian Agama (KEMENAG) Kabupaten Bima.

Ha $; \beta \neq 0$, Terdapat pengaruh Budaya Organisasi secara signifikan terhadap Kinerja Pegawai pegawai pada Kementerian Agama (KEMENAG) Kabupaten Bima.

\section{METODOLOGI PENELITIAN}

\section{Jenis Penelitian}

Jenis penelitian yang di gunakan dalam penelitian ini adalah penelitian asosiatif. Penelitian asosiatif adalah penelitian yang bertujuan untuk mengetahui hubungan antara dua variabel (Sugiyono,2018).

\section{Operasional Variabel}

\section{a. Budaya Organisasi $(\mathbf{X})$}

Budaya organisasi sebagai sebuah sistem makna bersama yang dianut oleh para anggota organisasi yang membedakan organisasi tersebut dengan organisasi lain.

\section{b. Kinerja Pegawai (Y)}

Kinerja pegawai (prestasi kerja) adalah hasil kerja secara kualitas dan kuantitas yang dicapai oleh seseorang pegawai dalam melaksanakan tugasnya sesuai dengan tanggung jawab yang diberikan kepadanya.

\section{Uji Validitas dan Uji Reabilitas}

\section{a.Uji validitas}

Uji Validitas adalah sejauh mana ketepatan dan kecermatan suatu alat ukur dalam melakukan fungsi ukurnya (Azwar, 2016). Biasanya syarat 
minimum untuk dianggap valid dan memenuhi syarat adalah kalau $r=0,300$ atau lebih. Jadi kalau korelasi antara butir dengan skor total kurang dari 0,3 maka dinyatakan tidak valid.

\section{b. Uji Reliabilitas}

Uji reliabilitas adalah suatu pengujian yang dilakukan untuk mengetahui apakah item-item penyataan dapat dipercaya keakuratannya atau tidak. Syarat untuk menyatakan bahwa butir instrument dinyatakan reliabel biasanya apabila nilai Cronbach's Alfa sama dengan atau lebih besar dari 0,6 (Cronbach's Alfa $\geq 0,6$ ) dan apabila nilainya berada dibawah 0,6 maka dinyatakan tidak reliabel atau kurang dapat dipercaya. (Azwar, 2016).

\section{Analisis Regresi Linier sederhana}

Analisis yang digunakan dalam penelitian ini adalah analisis regresi sederhana yaitu Metode Statistik yang berfungsi untuk menguji sejauh mana hubungan sebab akibat antara Variabel Faktor Penyebab (X) terhadap Variabel Akibatnya.

\section{Uji Korelasi Sederhana $(R)$}

Korelasi sederhana adalah suatu korelasi yang bermaksud untuk melihat hubungan antara 2 variabel (variabel dependent dan satu variabel independent).

\section{Uji Koefisien determinasi $\left(\mathbf{R}^{2}\right)$}

Koefisien determinasi $\left(\mathrm{R}^{2}\right)$ digunakan untuk mengetahui presentasi variabel independen secara bersama sama dapat menjelaskan variabel dependen. Nilai koefisien determinasi adalah antara nol dan satu. Jika koefisien determinasi $\left(\mathrm{R}^{2}\right)=1$, artinya variabel independent memberikan semua informasi yang dibutuhkan untuk memprediksi variasi variabel dependen. Jika koefisisen determinasi $\left(\mathrm{R}^{2}\right)=0$, artinya variabel independen tidak mampu menjelaskan variasi variabel dependen dengan menggunakan bantuan SPSS.

\section{Uji Parsial (Uji t-statistik)}

Uji parsial dengan $t$ test ini bertujuan untuk mengetahui besarnya pengaruh masing-masing variabel independent secara individu (Parsial) terhadap variabel dependen. Pengujian $t$ dilakukan dengan membandingkan $t$ hitung dengan $\mathrm{t}$ tabel. Jika $\mathrm{t}$ hitung lebih besar dari t tabel pada tingkat kepercayaan $95 \%$ atau ( $\mathrm{p}$ - value $<0,05$ ), maka Ha diterima,yang artinya variabel independen yang diuji secara parsial mempunyai pengaruh terhadap variabel dependent.

\section{HASIL PENELITIAN}

\section{Uji Validitas dan Uji Reliabilitas}

\section{a. Uji Validitas}

Pengujian Validitas dilakukan untuk mengetahui valid tidaknya suatu kuesioner dari masing-masing variable tersebut. Uji validitas yang telah dilakukan dalam penelitian ini ditampilkan dalam tabel berikut:

Tabel 1. Hasil Uji Validitas

\begin{tabular}{|c|c|c|c|c|}
\hline Variabel & Item & $\begin{array}{c}\text { Nilai } \\
\text { Validity }\end{array}$ & $\begin{array}{c}\text { Standar } \\
\text { Validitas }\end{array}$ & Ket \\
\hline
\end{tabular}




\begin{tabular}{|c|c|c|c|c|}
\hline \multirow{4}{*}{} & 1 & 0,684 & 0,300 & Valid \\
\cline { 2 - 5 } & 2 & 0,540 & 0,300 & Valid \\
\cline { 2 - 5 } & 3 & 0,470 & 0,300 & Valid \\
\cline { 2 - 5 } Budaya & 4 & 0,489 & 0,300 & Valid \\
\cline { 2 - 5 } & 5 & 0,576 & 0,300 & Valid \\
\cline { 2 - 5 } & 6 & 0,432 & 0,300 & Valid \\
\cline { 2 - 5 } & 7 & 0,509 & 0,300 & Valid \\
\cline { 2 - 5 } & 8 & 0,461 & 0,300 & Valid \\
\cline { 2 - 5 } & 10 & 0,692 & 0,300 & Valid \\
\cline { 2 - 5 } & 11 & 0,419 & 0,300 & Valid \\
\cline { 2 - 5 } & 12 & 0,798 & 0,300 & Valid \\
\cline { 2 - 5 } & 13 & 0,514 & 0,300 & Valid \\
\cline { 2 - 5 } & 14 & 0,546 & 0,300 & Valid \\
\hline \multirow{5}{*}{ Kinerja } & 1 & 0,888 & 0,300 & Valid \\
\cline { 2 - 5 } & 2 & 0,461 & 0,300 & Valid \\
\cline { 2 - 5 } & 3 & 0,415 & 0,300 & Valid \\
\cline { 2 - 5 } & 4 & 0,584 & 0,300 & Valid \\
\cline { 2 - 5 } & 5 & 0,384 & 0,300 & Valid \\
\cline { 2 - 5 } & 6 & 0,527 & 0,300 & Valid \\
\cline { 2 - 5 } & 7 & 0,558 & 0,300 & Valid \\
\cline { 2 - 5 } & 8 & 0,605 & 0,300 & Valid \\
\cline { 2 - 5 } & 9 & 0,622 & 0,300 & Valid \\
\cline { 2 - 5 } & 10 & 0,528 & 0,300 & Valid \\
\cline { 2 - 5 } & 11 & 0,363 & 0,300 & Valid \\
\cline { 2 - 5 } & 12 & 0,523 & 0,300 & Valid \\
\hline
\end{tabular}

Sumber: Data Primer Diolah Spss v22 2021

Dari hasil pengujian validitas pada tabel diatas, kuesioner yang berisi dari 2 variabel ini ada 26 kuesioner yang telah diisi oleh 34 responden pada penelitian ini. Salah satu cara agar bisa mengetahui kuesioner mana yang valid dan tidak valid, kita harus mencari tau $r$ tabelnya terlebih dahulu. Rumus dari $r$ tabel adalah $\mathrm{df}=\mathrm{N}-2$ jadi $34-2=32$, sehingga $\mathrm{r}$ tabel $=0,300$. Dari hasil perhitungan validitas pada tabel diatas, dapat dilihat bahwa $r$ hitung $>r$ tabel ada 26 kuisioner yang dinyatakan valid semua, 26 kuesioner semua dinyatakan valid karena semua $r$ hitung lebih dari $r$ table $=0,300$.

\section{b. Uji Reliabilitas}

Uji reliabilitas dilakukan terhadap item pertanyaan yang dinyatakan valid. Suatu variabel dikatakan reliabel atau handal jika jawaban terhadap pertanyaan selalu konsisten. Koefisien reliabilitas instrumen dimaksudkan untuk melihat konsistensi jawaban butir-butir pernyataan yang diberikan oleh responden Adapun alat analisisnya menggunakan metode belah dua (split half) dengan mengkorelasikan total skor ganjil lawan genap, selanjutnya dihitung reliabilitasnya menggunakan rumus "Alpha Cronbach'. Penghitungan dilakukan dengan dibantu komputer program SPSS. Adapun reliabilitas untuk masing-masing variabel hasilnya disajikan pada tabel berikut ini.

Tabel 2. Hasil Uji Reliabilitas 


\begin{tabular}{|l|c|c|c|c|}
\hline \multicolumn{1}{|c|}{ Variabel } & Jumlah Item & Alpha & Standar & Ket \\
\hline Budaya organisasi & 14 & 0,813 & 0,600 & Reliabel \\
\hline Kinerja Pegawai & 12 & 0,776 & 0,600 & Reliabel \\
\hline
\end{tabular}

Sumber: Data Primer Diolah Spss v22 2021

Berdasarkan Tabel 2 uji reliabilitas, suatu variabel dikatakan reliabel atau handal jika jawaban terhadap pertanyaan selalu konsisten. Jadi hasil koefisien reliabilitas variabel budaya organisasi $(\mathrm{X})$ adalah sebesar $\mathrm{rll}=0,813$, variabel kinerja pegawai (Y) adalah sebesar rll $=0,776$, ternyata memiliki nilai "Alpha Cronbach" lebih dari 0,600, yang berarti kedua variabel dinyatakan reliable atau memenuhi persyaratan.

\section{Regresi Linier Sederhana}

Tabel 3. Hasil Uji Regresi Linear sederhana Coefficients $^{\mathrm{a}}$

\begin{tabular}{|c|c|c|c|c|c|}
\hline \multirow[b]{2}{*}{ Model } & \multicolumn{2}{|c|}{ Unstandardized Coefficients } & \multirow{2}{*}{$\begin{array}{c}\text { Standardized } \\
\text { Coefficients } \\
\text { Beta }\end{array}$} & \multirow[b]{2}{*}{$\mathrm{t}$} & \multirow[b]{2}{*}{ Sig. } \\
\hline & B & Std. Error & & & \\
\hline $\begin{array}{c}\text { (Constant) } \\
\text { Budaya Organisasi }\end{array}$ & $\begin{array}{c}12.943 \\
.666\end{array}$ & $\begin{array}{c}5.190 \\
.090\end{array}$ & .794 & $\begin{array}{l}2.494 \\
7.383\end{array}$ & $\begin{array}{l}.018 \\
.000\end{array}$ \\
\hline
\end{tabular}

a. Dependent Variable: Kinerja Pegawai

Sumber: Data Primer Diolah Spss v22 2021

Dari hasil analisis regresi dapat diketahui persamaan regresi linear sederhana sebagai berikut:

$\mathrm{Y}=\mathrm{a}+\mathrm{bX}$

$\mathrm{Y}=12,943+(0,794) \mathrm{X}$

Berdasarkan persamaan tersebut, maka dapat dijelaskan sebagai berikut:

a. Nilai konstanta sebesar 12,943 dapat diartikan apabila variabel budaya organisasi dianggap nol, maka kinerja pegawai akan sebesar 12,943.

b. Nilai koefisien beta pada variabel budaya organisasi sebesar 0,794 artinya setiap perubahan variabel budaya organisasi (X) sebesar satu satuan, maka akan mengakibatkan perubahan kinerja pegawai sebesar 0,794 satuan, dengan asumsi-asumsi yang lain adalah tetap. Peningkatan satu satuan pada variabel budaya organisasi akan meningkatkan kinerja pegawai sebesar 0,794 satuan.

\section{Koefisien Koefisien Korelasi Sederhana}

Hasil Uji koefisien korelasi sederhana diperoleh nilai $\mathrm{R}$ adalah sebesar 0,794 (79,4\%). Hasil tersebut menjelaskan bahwa terdapat hubungan (korelasi) antara pengembangan karir terhadap kepuasan kerja pegawai. Untuk dapat memberi interpretasi terhadap kuatnya pengaruh itu maka dapat digunakan pedoman seperti pada tabel berikut: 
Tabel 4. Pembanding Tingkat Hubungan Koefisien Korelasi

\begin{tabular}{|c|c|}
\hline Interval koefisien & Tingkat Hubungan \\
\hline $0,00-0,199$ & Sangat Rendah \\
$0,20-0,399$ & Rendah \\
$0,40-0,599$ & Sedang \\
$0,60-0,799$ & Kuat \\
$0,80-1,000$ & Sangat Kuat \\
\hline
\end{tabular}

Sumber: Sugiyono 2018

Jadi kolerasi hubungan pengembangan karir terhadap kepuasan kerja sebesar 0,794 $(79,4 \%)$ dengan tingkat hubungan yang kuat..

\section{Uji Koefisien Determinasi}

Tabel 5. Hasil Uji Koefisien Determinasi Model Summary

\begin{tabular}{|c|c|c|c|c|}
\hline Model & $\mathrm{R}$ & R Square & Adjusted R Square & $\begin{array}{c}\text { Std. Error of the } \\
\text { Estimate }\end{array}$ \\
\hline 1 & $.794^{\mathrm{a}}$ & .630 & .619 & 3.10472 \\
\hline
\end{tabular}

a. Predictors: (Constant), Budaya Organisasi

Sumber: Data Primer Diolah Spss v22 2021

Tabel tersebut menjelaskan besarnya pengaruh $\left(R^{2}\right)$ yaitu sebesar 0,630 dan menjelaskan besarnya prosentase pengaruh variabel bebas terhadap variabel terikat yang disebut koefisien determinasi yang merupakan hasil dari pengkuadratan $\mathrm{R}$. Dari output tersebut diperoleh koefisien determinasi $\left(R^{2}\right)$ sebesar 0,630, yang mengandung pengertian bahwa pengaruh variabel bebas (budaya organisasi) terhadap variabel terikat (kinerja pegawai) adalah sebesar 63\%, sedangkan sisanya yaitu $37 \%$ dipengaruhi oleh variabel lain. Hasil tersebut menjelaskan bahwa terdapat pengaruh antara budaya orgaisasi terhadap kinerja pegawai.

\section{Uji t ( Uji Parsial)}

Uji $\mathrm{t}$ digunakan untuk mengetahui pengaruh dari masing-masing variabel bebas terhadap variabel terikat. Untuk melihat pengaruh secara parsial maka pengambilan keputusan menggunakan cara sebagai berikut:

- Jika $\mathrm{t}_{\text {tabel }}<\mathrm{t}_{\text {hitung }}$ dan $<\mathrm{t}_{\text {tabel }}$ maka $\mathrm{H}_{0}$ diterima.

- Jika $\mathrm{t}_{\text {hitung }}<\mathrm{t}_{\text {tabel }}$ dan $\mathrm{t}_{\text {hitung }}>\mathrm{t}_{\text {tabel }}$ maka $\mathrm{H}_{0}$ ditolak.

- Rumus mencari t-table :

Besarnya nilai df atau derajat kebebasan adalah :

$\mathrm{Df}=\mathrm{n}-\mathrm{k}-1$

$\mathrm{Df}=34-1-1=32$

Sehingga nilai $\mathrm{t}_{\text {tabel }}=\mathrm{t}(\mathrm{n}-\mathrm{k}-1 ; \mathrm{alpha})=\mathrm{t}(32,0.05)=2.039$

Tabel 6. Hasil Uji T

Coefficients $^{\mathrm{a}}$ 


\begin{tabular}{|c|c|c|c|c|c|}
\hline \multirow[b]{2}{*}{ Model } & \multicolumn{2}{|c|}{ Unstandardized Coefficients } & \multirow{2}{*}{$\begin{array}{c}\text { Standardized } \\
\text { Coefficients } \\
\text { Beta }\end{array}$} & \multirow[b]{2}{*}{$\mathrm{t}$} & \multirow[b]{2}{*}{ Sig. } \\
\hline & B & Std. Error & & & \\
\hline $\begin{array}{cc} & \text { (Constant) } \\
\text { Budaya Organisasi }\end{array}$ & $\begin{array}{c}12.943 \\
.666\end{array}$ & $\begin{array}{c}5.190 \\
.090\end{array}$ & .794 & $\begin{array}{l}2.494 \\
7.383\end{array}$ & $\begin{array}{l}.018 \\
.000\end{array}$ \\
\hline
\end{tabular}

a. Dependent Variable: Kinerja Pegawai

Sumber: Data Primer Diolah Spss v22 2021

Hasil H1 : Apakah Budaya Organisasi berpengaruh secara signifikan terhadap Kinerja Pegawai pada kantor Kementerian Agama (KEMENAG) Kabupaten Bima.

Hasil statistik uji $t$ untuk variabel harapan diperoleh nilai $t_{\text {hitung }}$ sebesar 7,383 lebih besar dari pada nilai $t_{\text {tabel }}$ sebesar 2.039 dengan nilai signifikansi sebesar 0,000 lebih kecil dari $0,05(0,000<0,05) . \mathrm{H}_{\mathrm{o}}$ ditolak dan $\mathrm{H}_{\mathrm{a}}$ diterima. Maka dapat disimpulkan bahwa budaya organisasi berpengaruh terhadap kinerja pegawai pada kantor Kementerian Agama (KEMENAG) Kab.Bima.

Adanya hubungan yang signifikan antara budaya organisasi dengan kinerja pegawai.Hal ini menunjukkan bahwa salah satu faktor yang menentukan kinerja pegawai adalah budaya organisasi.Hasil penelitian ini memperkuat pendapat ahli, Sutrisno (2010), budaya organisasi merupakan suatu kekuatan sosial yang tidak tampak, yang dapat menggerakkan orang-orang dalam suatu organisasi untuk melakukan aktivitas kerja. Budaya organisasi yang benar-benar dikelola sebagai alat manajemen akan berpengaruh dan menjadi pendorong bagi karyawan untuk berperilaku positif, dedikatif, dan produktif. Dimana budaya organisasi yang kuat atau positif akan mempengaruhi kinerja organisasi tersebut sehingga mendukung tujuantujuan perusahaan, sebaliknya yang lemah atau negatif akan berdampak buruk terhadap pencapaian tujuan suatu organisasi.

Berdasarkan uraian di atas dapat disimpulkan bahwa budaya organisasi sangat mempengaruhi kinerja pegawai. Hasil penelitian ini memperlihatkan bahwa adanya hubungan yang siginifikan (berarti) antar budaya organisasi dengan kinerja pegawai. Artinya semakin baik budaya organisasi maka semakin baik pula kinerja pegawai. Sebaliknya apabila budaya organisasi semakin kurang baik maka kinerja pegawai akan menurun. Sehingga kedua variabel harus samasama ditingkatkan agar menjadi baik dan sesuai dengan yang diharapkan (Putri, 2015).

\section{KESIMPULAN}

Budaya organisasi berpengaruh positif terhadap kinerja pegawai. Berdasarkan hasil statistik uji t untuk variabel diperoleh nilai thitung sebesar 7,383 lebih besar dari pada nilai ttabel sebesar 2,039 dengan nilai signifikansi sebesar 0,000 lebih kecil dari 0,05 $(0,000<0,05)$. Ho ditolak dan Ha diterima. Maka dapat disimpulkan bahwa budaya organisasi berpengaruh secara signifikan terhadap kinerja pegawai pada kantor Kementerian Agama (KEMENAG) Kab. Bima. Saran bagi Kementrian Agama Kab. Bima Mengingat variabel bebas dalam penelitian ini merupakan hal yang baik dalam mempengaruhi kinerja pegawai. Diharapkan bagi organisasi untuk terus meningkatkan kinerja pegawainya pada kantor Kementerian Agama Kabupaten Bima. Diharapkan hasil penelitian ini juga dapat dipakai sebagai acuan bagi peneliti selanjutnya untuk mengembangkan penelitian ini dengan 
mempertimbangkan varibel-variabel selain yang digunakan dalam penelitian ini.

\section{DAFTAR PUSTAKA}

Azwar. 2016. Metode penelitian. Yogyakarta:Pustaka Pelajar.

Ghozali, Imam. 2013. Aplikasi Analisis Multivariate dengan Program IBM SPSS 21

Update PLS Regresi. Semarang: Badan Penerbit Universitas Diponegoro.

Gibson. 2003. Organisasi : Perilaku, struktur dan proses. Jakarta: Penerbit Erlangga.

Hasibuan, Malayu. 2012. Manajemen Sumber Daya Manusia, Edisi Revisi. Jakarta: Bumi Aksara

Jusmin, A. 2013. AnalisisPengaruh Budaya Organisasi Terhadap Kinerja Pegawai pada Kantor Administrasi Perhubungan Jayapura. Papua: Universitas Yapis Papua.

Mangkunegara, Anwar Prabu, 2012. Evaluasi Kinerja Sumber Daya Manusia, cetakan keenam.Bandung: Rafika Aditama

Putri, R.E. 2015. Hubungan Budaya Organisasi dengan Kinerja Pegawai Pada Kantor Badan Pengendalian Dampak Lingkungan Daerah Kota Padang. Padang: Universitas Negeri Padang.

Robbins, Stephen P. 2007. Perilaku Organisasi, Jilid I dan II, alih Bahasa : Hadyana Pujaatmaja. Jakarta: Prenhallindo.

Robbins, Stephen P. 2012. Organizational Behaviour. Cetakan ke-5. New Jersey, New York : Prentice Hall International Inc.

Sedarmayanti. 2011. Sumber Daya Manusia dan Produktivitas Kerja. Bandung :: Mandar Maju.

Sutrisno, E. 2010. Manajemen Sumber Daya Manusia, Edisi Pertama. Cetakan Pertama. Jakarta : Penerbit Kencana.

Sugiyono. 2018. Metode Penelitian Kuantitatif, Kualitatif, dan R\&D. Bandung: ALFABETA, CV.

Tika H. Moh. Pabundu, 2006. Budaya Organisasi dan Peningkatan Kinerja Perusahaan, Cetakan Pertama, Jakarta. PT. Bhumi Aksara,

Wirawan, 2007. Budaya dan Iklim Organisasi. Jakarta : Salemba Empat.

Wibowo. (2010). Manajemen kinerja.edisi revisi. Jakarta : PT. Raja Grafindo Persada. 